\title{
Phylogenetic relationships of Hemidactylus geckos from the Gulf of Guinea islands: patterns of natural colonizations and anthropogenic introductions estimated from mitochondrial and nuclear DNA sequences
}

\author{
José Jesus $^{\mathrm{a}}$, Antonio Brehm ${ }^{\mathrm{a}}$, D. James Harris, ${ }^{\mathrm{b}, *}$ \\ ${ }^{a}$ Centre of Macaronesian Studies, University of Madeira, Penteada, 9000 Funchal, Portugal \\ ${ }^{\mathrm{b}}$ Centro de Investigação em Biodiversidade e Recursos Genéticos (CIBIO\UP), ICETA, Campus Agrario de Vairão, \\ 4485-661 Vila do Conde, Portugal \\ Received 26 February 2004; revised 16 September 2004 \\ Available online 1 January 2005
}

\begin{abstract}
Mitochondrial DNA (12S rRNA, 16S rRNA, and cytochrome $b$ ) sequences and nuclear sequences (C-mos and $\alpha$-Enolase) were analyzed within all known Hemidactylus species from all three volcanic islands in the Gulf of Guinea that have never been connected to the continent. These comprise both endemic and widespread species. Our aim was to determine if the widespread species was introduced anthropogenically, to determine the number of distinct genetic lineages within the islands, and to determine if the endemic forms constituted a monophyletic group. Our results suggest that a previously undescribed species on São Tomé is the sister taxon to Hemidactylus newtoni, endemic to Annobon. Genetic variation between populations of Hemidactylus greefii from São Tomé and Principe is very high based on mtDNA sequences, but the forms cannot be distinguished using the nuclear DNA sequences. Hemidactylus mabouia appears to have been anthropogenically introduced to all three islands. The island endemics do not form a monophyletic group, suggesting multiple independent colonizations of the islands.
\end{abstract}

(C) 2004 Elsevier Inc. All rights reserved.

Keywords: 12S rRNA; 16S rRNA; C-mos; Enolase; Hemidactylus; São Tomé; Principe; Annobon

\section{Introduction}

The forests of West Africa, including the islands of the Gulf of Guinea (Fig. 1) comprise one of the world's biodiversity hotspots (Myers et al., 2000). The volcanic chain was formed during the middle to late Tertiary. Bioko (formerly Fernando Po) is the largest and closest to Africa, only about $32 \mathrm{~km}$ from Cameroon. Smaller and more geographically isolated are São Tomé and Principe (1001 $\mathrm{km}^{2}$ combined), that include a number of

\footnotetext{
${ }^{*}$ Corresponding author. Fax: +351 252661780.

E-mail address: james@mail.icav.up.pt (D.J. Harris).
}

small islets, and $160 \mathrm{~km}$ southwest of São Tomé, Annobon $\left(17 \mathrm{~km}^{2}\right)$. While Bioko was connected to the continent during sea-level fluctuations in the last glacial periods, the other islands have never been connected and are separated by deep-sea trenches. Thus while the herpetofauna of Bioko is essentially continental in nature, the remaining islands harbor far fewer species but far more endemics. Oldest geological dates for Principe, São Tomé, and Annobon are 31, 14, and 4.8 my, respectively (Lee et al., 1994).

Although many phylogenetic studies have been performed on the herpetofauna of the more northern Atlantic volcanic islands, such as the Cape Verdes (Carranza et al., 2001; Jesus et al., 2001, 2002a), Canary 


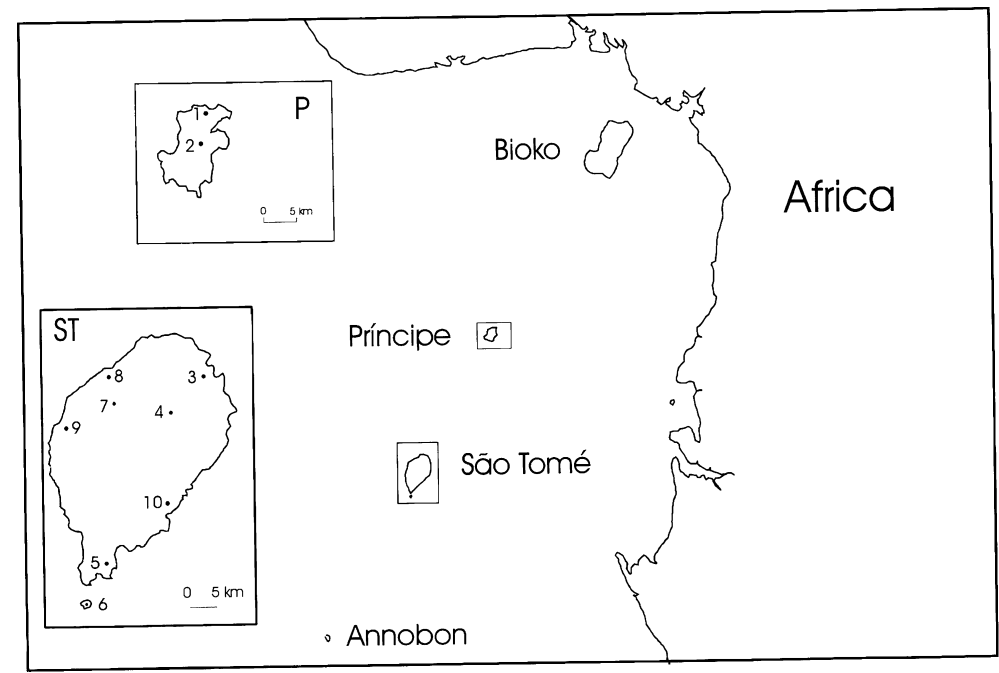

Fig. 1. Map showing the sampling localities of Hemidactylus from the Gulf of Guinea. The Cape Verde islands are also located off the West Coast of Africa, but over $2000 \mathrm{~km}$ to the North. Localities of $H$. bouvieri and $H$. brookii, for which $12 \mathrm{~S}$ rRNA sequences were already published but additional sequences were generated, are given in Jesus et al. (2001).

Islands (Carranza et al., 2000; Thrope et al., 1994), and Madeiran archipelago (Brehm et al., 2003), very little is known about the herpetofauna of the islands of the Gulf of Guinea. This is especially true of the geckos Hemidactylus, a genus of over 80 morphologically similar species found across Africa, Asia, and South America. Often commensal, they have been repeatedly translocated by humans, as shown by the recent report of an introduced population of Hemidactylus mabouia on Madeira (Jesus et al., 2002b). An extensive revision of Hemidactylus from Madagascar and the Indian Ocean islands indicated a complex pattern of anthropogenic introductions and natural colonizations (Vences et al., 2004). These introductions have serious conservation implications - in the Mascarene islands Nactus geckos have possibly been eliminated from some islands by introduced Hemidactylus frenatus (Arnold, 2000). However, no broad-scale phylogeny for Hemidactylus is available. In this paper, we attempt to unravel relationships of Hemidactylus from the Gulf of Guinea islands, including both endemic (Hemidactylus newtoni and Hemidactylus greefii) and the widespread species (H. mabouia). Using both mitochondrial and nuclear DNA sequences we aim to (a) distinguish natural island colonizations from recent anthropogenic introductions, (b) determine the number of genetically distinct lineages on the islands, and (c) determine the relationship of all known island species to other Hemidactylus species.

\section{Materials and methods}

The number and geographic locations of the specimens used in this study are given in Table 1 and Fig. 1.
Total genomic DNA was extracted from small pieces of tail using standard methods (Sambrook et al., 1989). Primers used in both amplification and sequencing of mitochondrial DNA were 16SL and $16 \mathrm{SH}, 12 \mathrm{Sa}$ and $12 \mathrm{Sb}$, and cytochrome $b 1$ and 3 from Kocher et al. (1989). Amplification conditions were the same as described by Harris et al. (1998). Primers used to amplify a fragment of the nuclear gene C-mos were G73 and G74, and were used following the conditions given in Saint et al. (1998). C-mos sequences have been widely used to infer relationships at many levels within geckos (e.g. Austin et al., 2004; Carranza et al., 2002; Harris et al., 2004a,b). $\alpha$-Enolase is an enzyme involved in glycosis. The primers used (Enol L731 and H912; Friesen et al., 1997) amplify intron eight, and small parts of exons eight and nine. In a recent study this region was more variable than C-mos within skinks, and within a single genus, Scelotes (Whiting et al., 2003). Amplified fragments were sequenced on a 310 Applied Biosystem DNA Sequencing Apparatus. Sequences were aligned using Clustal W (Thompson et al, 1994). Two loop regions of the $16 \mathrm{~S}$ rRNA fragment (totaling $53 \mathrm{bp}$ ) could not be unambiguously aligned, and were excluded from further analyses. Initially we sequenced all $53 \mathrm{Hemi-}$ dactylus samples from the Gulf of Guinea for the fragment of $12 \mathrm{~S}$ rRNA and compared this to eight published sequences- $H$. frenatus (Whiting et al., 2003), H. mabouia from Madeira (Jesus et al., 2002b) and the Cape Verdes (Jesus et al., 2001), H. brooki from Guinea and the Cape Verdes (Jesus et al., 2001), and three H. bouvieri from the Cape Verdes (Jesus et al., 2001). All H. mabouia were identical for this marker. To confirm that the $H$. mabouia showed very low genetic variation we sequenced three individuals from each island for $700 \mathrm{bp}$ of the faster evolving gene cytochrome $b$. We then 
Table 1

Specimens used in this study

\begin{tabular}{|c|c|c|}
\hline Species & Locality & Code \\
\hline Hemidactylus mabouia & São Nicolau_-ST4 & 726 \\
\hline Hemidactylus mabouia & São Nicolau_-ST4 & 554 \\
\hline Hemidactylus mabouia & São Nicolau-ST4 & 555 \\
\hline Hemidactylus mabouia & São Nicolau-ST4 & 556 \\
\hline Hemidactylus mabouia & São Nicolau-ST4 & 728 \\
\hline Hemidactylus mabouia & São Nicolau—ST4 & 732 \\
\hline Hemidactylus mabouia & São Nicolau_-ST4 & 737 \\
\hline Hemidactylus mabouia & São Nicolau_-ST4 & 739 \\
\hline Hemidactylus mabouia & São Nicolau_-ST4 & 740 \\
\hline Hemidactylus mabouia & São Nicolau—ST4 & 741 \\
\hline Hemidactylus mabouia & São Nicolau-ST4 & 742 \\
\hline Hemidactylus mabouia & São Nicolau-ST4 & 743 \\
\hline Hemidactylus mabouia & São Nicolau—ST4 & 744 \\
\hline Hemidactylus mabouia & São Nicolau_-ST4 & 745 \\
\hline Hemidactylus mabouia & São Nicolau—ST4 & 746 \\
\hline Hemidactylus mabouia & São Nicolau—ST4 & 748 \\
\hline Hemidactylus mabouia & Santa Catarina - ST9 & 747 \\
\hline Hemidactylus mabouia & Monte Mário_-ST5 & 533 \\
\hline Hemidactylus mabouia & Monte Mário-ST5 & 534 \\
\hline Hemidactylus mabouia & Monte Mário_-ST5 & 735 \\
\hline Hemidactylus mabouia & Neves-ST8 & 549 \\
\hline Hemidactylus mabouia & Neves-ST8 & 550 \\
\hline Hemidactylus mabouia & Neves-ST8 & 551 \\
\hline Hemidactylus mabouia & Neves-ST8 & 544 \\
\hline Hemidactylus mabouia & Neves-ST8 & 545 \\
\hline Hemidactylus mabouia & Cavalete-ST10 & 709 \\
\hline Hemidactylus mabouia & Cavalete-ST10 & 773 \\
\hline Hemidactylus mabouia & São Tomé-ST3 & 723 \\
\hline Hemidactylus mabouia & São Tomé-ST3 & 730 \\
\hline Hemidactylus mabouia & Ilhéu das Rolas-ST6 & 557 \\
\hline Hemidactylus mabouia & Ilhéu das Rolas-ST6 & 558 \\
\hline Hemidactylus mabouia & Ponta do Sol—P1 & 753 \\
\hline Hemidactylus mabouia & Ponta do Sol-P1 & 754 \\
\hline Hemidactylus mabouia & Ponta do Sol-P1 & 755 \\
\hline Hemidactylus mabouia & Annobon & 668 \\
\hline Hemidactylus mabouia & Annobon & 669 \\
\hline Hemidactylus mabouia & Annobon & 670 \\
\hline Hemidactylus newtoni & Annobon & 667 \\
\hline Undescribed species & São Nicolau_-ST4 & 722 \\
\hline Hemidactylus greefii & Vale do Contador-ST7 & 569 \\
\hline Hemidactylus greefii & Vale do Contador-ST7 & 571 \\
\hline Hemidactylus greefii & Nova Estrela-P2 & 590 \\
\hline Hemidactylus greefii & Nova Estrela-P2 & 591 \\
\hline Hemidactylus greefii & Nova Estrela-P2 & 597 \\
\hline Hemidactylus greefii & Nova Estrela-P2 & 598 \\
\hline Hemidactylus greefii & Nova Estrela-P2 & 701 \\
\hline Hemidactylus greefii & Nova Estrela-P2 & 702 \\
\hline Hemidactylus greefii & Nova Estrela-P2 & 703 \\
\hline Hemidactylus greefii & Nova Estrela-P2 & 704 \\
\hline Hemidactylus mabouia & Nova Estrela-P2 & 705 \\
\hline Hemidactylus greefii & Nova Estrela-P2 & 706 \\
\hline Hemidactylus greefii & Nova Estrela-P2 & 717 \\
\hline Hemidactylus greefii & Nova Estrela-P2 & 718 \\
\hline Hemidactylu bouvieri & $\begin{array}{l}\text { Boavista-Sal Rei- } \\
\text { Cabo Verde Islands }\end{array}$ & CV125 \\
\hline Hemidactylu bouvieri & $\begin{array}{l}\text { Boavista-Sal Rei- }- \\
\text { Cabo Verde Islands }\end{array}$ & CV38 \\
\hline Hemidactylus bouvieri & Sal_Cabo Verde & \\
\hline Hemidactylus brookii & Bissau-Guiné & 782 \\
\hline Hemidactylus brookii & $\begin{array}{l}\text { Santo Antão- } \\
\text { Cabo Verde }\end{array}$ & HB38 \\
\hline
\end{tabular}

Localities refer to Fig. 1. Codes refer to voucher specimens and to Fig. 2. sequenced all the endemic Hemidactylus species, five individuals from two outgroup species $(H$. brookii and $H$. bouvieri) and at least three $H$. mabouia from each of the islands for a $500 \mathrm{bp}$ fragment of the $16 \mathrm{~S}$ rRNA. We used these combined 12S rRNA and 16S rRNA sequences for 37 taxa for our phylogenetic analyses. Cmos sequences were collected from specimens from all of the genetically distinct mtDNA lineages, five outgroups (two $H$. brookii and three $H$. bouvieri), and aligned against a published sequence of $H$. frenatus (Whiting et al., 2003). In total 20 sequences of $338 \mathrm{bp}$ were included in the analyses. Since the intron of $\alpha$-Enolase has been shown to evolve faster than C-mos in many reptiles (Whiting et al., 2003) we also sequenced nine $H$. greefii and seven $H$. mabouia for this marker. We failed to amplify $H$. newtoni.

Mitochondrial DNA sequences were imported into PAUP* 4.0b10 (Swofford, 2003) for phylogenetic analysis. For the phylogenetic analysis of the combined data, we used maximum likelihood (ML), maximum parsimony (MP), and Bayesian inference. When estimating phylogenetic relationships among sequences, one assumes a model of evolution. We used the approach outlined by Hulsenbeck and Crandall, 1997 to test 56 alternative models of evolution, employing PAUP* $4.0 \mathrm{~b} 10$ and Modeltest (Posada and Crandall (1998) described in detail in Posada and Crandall (2001)). Once a model of evolution was chosen, it was used to estimate a tree using ML (Felsenstein, 1981) with random sequence addition (10 replicate heuristic search). The MP analysis was also performed with random sequence addition (100 replicate heuristic search), and support for nodes was estimated using the nonparametric bootstrap technique (Felsenstein, 1985) with 1000 replicates. The Bayesian analysis was implemented using MrBayes (Huelsenbeck and Ronquist, 2001), which calculates Bayesian posterior probabilities using a Metropolis-coupled, Markov chain Monte Carlo (MC-MCMC) sampling approach. Bayesian analyses were conducted with random starting trees, run $0.5 \times 10^{6}$ generations, and sampled every 100 generations using a general-timereversible model of evolution with a gamma model of among-site rate variation. In both searches, stationarity of the Markov chain was determined as the point when sampled ln-likelihood values plotted against generation time reached a stable mean equilibrium value; "burn-in" data sampled from generations preceding this point were discarded. All data collected at stationarity were used to estimate posterior nodal probabilities and a summary phylogeny. Two independent replicates were conducted and inspected for consistency to check for local optima (Huelsenbeck and Bollback, 2001). New sequences from C-mos were aligned against $H$. frenatus. There were no indels. Because variation is low, the sequences were joined in a median network (Bandelt et al., 2000). Similarly for the sequences of $\alpha$-Enolase, variation was low 
within Hemidactylus, so sequences were joined in a network. A single base pair insertion was needed to align the sequences.

\section{Results}

For the combined 12S rRNA and 16S rRNA gene fragments, 37 taxa were included for a total of 930 base pairs; ML, MP, and Bayesian analyses gave identical estimates of relationships (Fig. 2). H. frenatus was used to root the trees. The most appropriate model for the combined data was the GTR model with an estimate of invariable sites $(0.50)$ and a discreet approximation of the gamma distribution (0.70). The ML heuristic search using this model found a single tree of - Ln 3151. Bayesian analysis produced an identical estimate of relationships. For MP 201 characters were informative, and the MP search found one tree of 434 steps (Fig. 2). In all analyses five clades, all with $100 \%$ Bayesian support, can be identified. The species $H$. bouvieri, H. brookii, and H. mabouia are all monophyletic units. H. bouvieri shows differentiation between samples from the two Cape Verde islands,
Sal and Boavista. H. greefii is monophyletic, and specimens from São Tomé and Principe are also reciprocally monophyletic. These two islands show a considerable degree of genetic distinctiveness, with an average of 3.3\% genetic divergence between them. The single sample of $H$. newtoni from Annobon is very distinct from any other samples, but it is clearly the sister taxon of an individual from an undescribed form from São Tomé. This form was noticeably darker and more robust than other specimens from São Tomé (unpublished data), but unfortunately it was the only sample of this kind that we collected. In all analyses $H$. greefi is the sister taxon to $H$. bouvieri from the Cape Verde islands and not to the other genetic lineages from the Gulf of Guinea islands.

In the combined analysis of $12 \mathrm{~S}$ and $16 \mathrm{~S}$ rRNA sequences, all $H$. mabouia from São Tomé (including the islet Rolas), Principe and Annobon are identical. Our sequences of $12 \mathrm{~S}$ rRNA from additional samples of $H$. mabouia (Table 1) confirm that all of the samples from the islands had an identical haplotype that was also shared by individuals on Madeira and the Cape Verde islands. Sequences from the faster-evolving cytochrome $b$ gene similarly showed no differences.

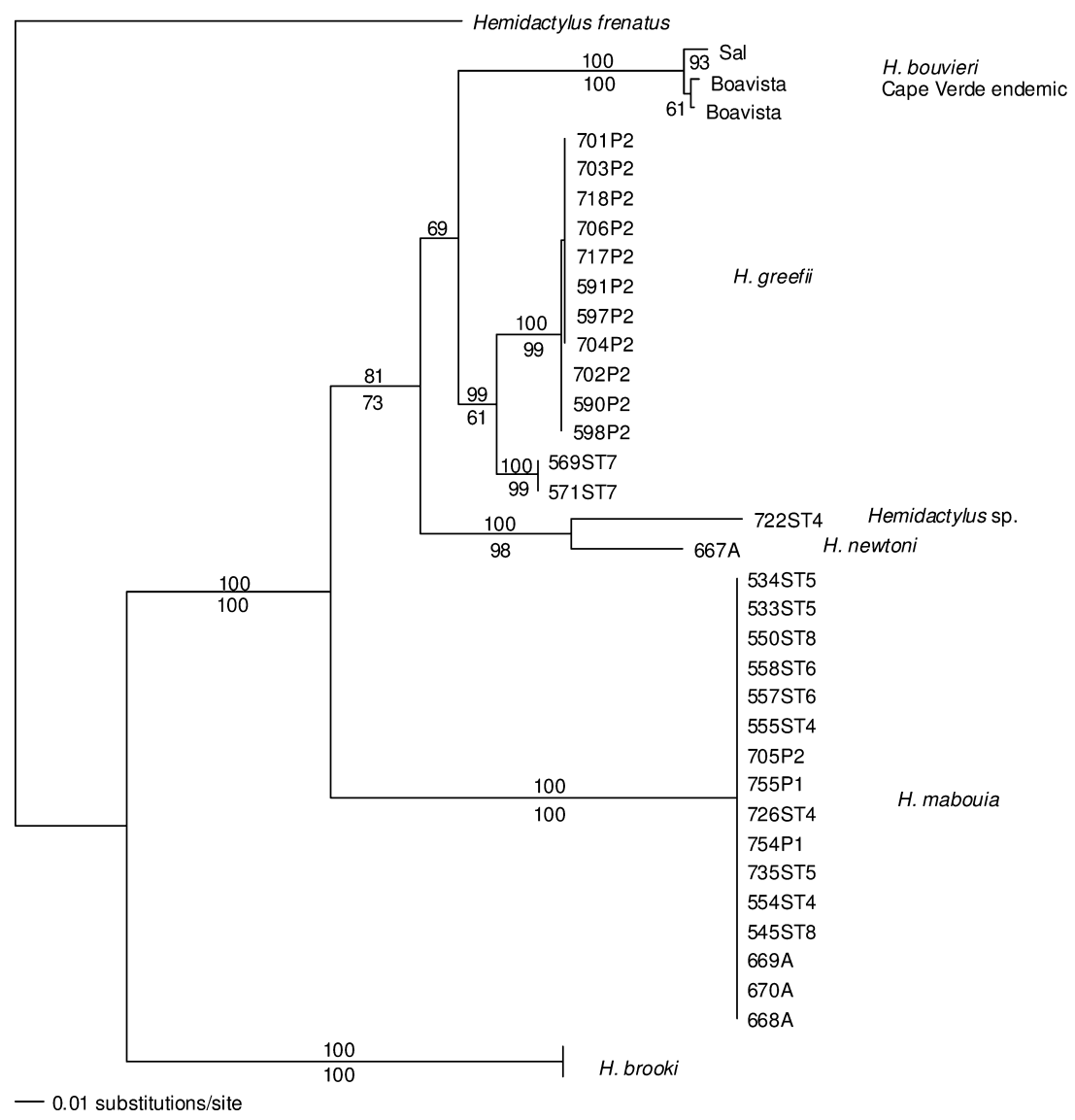

Fig. 2. Tree derived from a ML analysis of combined $12 \mathrm{~S}$ and $16 \mathrm{~S}$ rRNA fragments using the model described in the text. MP and Bayesian analyses gave identical estimates of relationships. Bootstrap values $(>50 \%)$ for MP are given below the nodes, and Bayesian probabilities are given above the nodes. The tree was rooted using $H$. frenatus. 


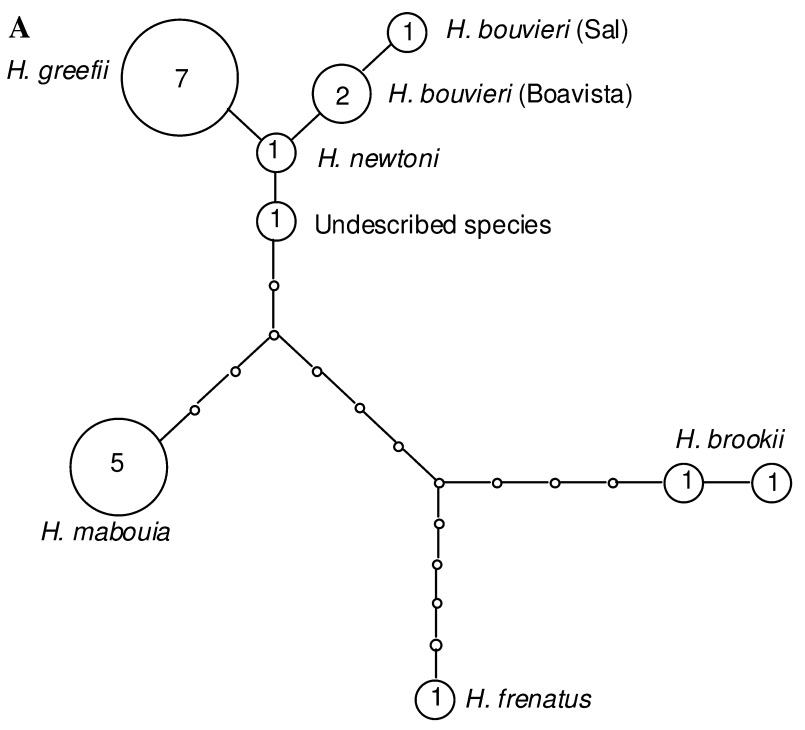

B $\mathrm{Pr}$

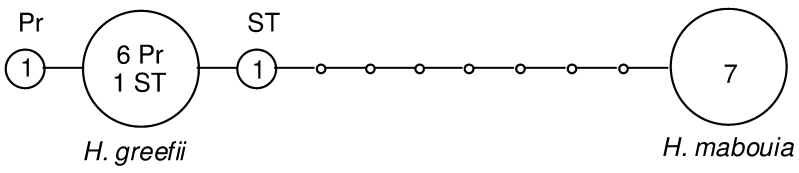

Fig. 3. Median networks showing relationships derived from partial sequences of C-mos (A) and $\alpha$-Enolase (B).

Our analyses of variation in C-mos nuclear DNA sequences is quite similar to our estimate of relationships derived from mtDNA (Fig. 3). H. greefii, H. newtoni, and the undescribed lineage from São Tomé all have unique haplotypes. $H$. bouvieri is closely related to these, while $H$. mabouia, $H$. brookii, and $H$. frenatus are more genetically differentiated. Despite the high mtDNA differentiation between $H$. greefii populations from São Tomé and Principe, they all share a single haplotype for C-mos. A similar case has been shown in Phelsuma geckos in the Mascarene islands (Austin et al., 2004). This result could be due to the slowly evolving nature of this region of the C-mos gene. However, we obtained the same result with the faster evolving $\alpha$-Enolase sequences (Fig. 3).

\section{Discussion}

Due to the known ease with which many Hemidactylus species are anthropogenically transported, it is often difficult to distinguish natural populations from introductions (Vences et al., 2004). The morphological conservativeness of some widespread forms further challenges taxonomists, such that $H$. brookii, H. mabouia, and $H$. frenatus are often confused (Vences et al., 2004). The molecular data presented here clearly separate these forms. The complete lack of genetic variation with these markers within $H$. mabouia from islands as geographically separate as São Tomé, the Cape Verdes and
Madeira, however, strongly indicate a recent anthropogenic introduction to all these islands. This conclusion is reinforced by the considerable genetic diversity revealed within island endemics, such as $H$. greefi $i$ and $H$. bouvieri.

Hemidactylus greefii populations from Principe and São Tomé are apparently monophyletic groups with respect to the mtDNA sequences. Differentiation between them is higher that that reported between Phelsuma lineages that appear to be distinct species (Austin et al., 2004). However, since we did not obtain any differentiation in two nuclear genes, we recommend maintaining the current taxonomy pending a more detailed morphological analysis. Sequences from $\alpha$-Enolase showed variation within $H$. greefii, while those from Cmos did not. Unfortunately we could not amplify this part of $\alpha$-Enolase for $H$. newtoni, so we could not use this marker in a more detailed phylogenetic analysis. Similarly Whiting et al. (2004) failed to amplify $H$. frenatus. However, it has been shown to be useful within Scelotes skinks (Whiting et al., 2004), and it may be a useful nuclear marker at lower taxonomic levels where C-mos is often uninformative.

Hemidactylus newtoni from Annobon is clearly a distinct species, endemic to this tiny island. Its sister taxon appears to be an undescribed species from São Tomé, from which it can be distinguished by mtDNA and nuclear C-mos sequences. The degree of divergence between these groups $(21 \%$ for the region of cytochrome $b$ sequenced) far exceeds that typically observed between reptile species (Harris, 2002). Our observations on Annobon suggest that introduced $H$. mabouia is now much more common than $H$. newtonii, and that both species share similar habitats (Jesus et al., 2003). This situation deserves careful monitoring.

None of our analyses suggest that the endemic Hemidactylus from these islands form a monophyletic unit. This result implies that the islands were colonized independently at least twice. One lineage from São Tomé presumably then colonized Annobon to give rise to $H$. newtoni.

\section{Conclusions}

Our study again highlights the extraordinarily high genetic diversity revealed within morphologically conservative gecko species (e.g., Austin et al., 2004; Harris et al., 2004a,b). Similar, widespread species such as $H$. brookii, $H$. frenatus, and $H$. mabouia, which are often mistaken for each other in the field, can be clearly differentiated. $H$. mabouia has been introduced to all three islands of the Gulf of Guinea, which has important conservation implications. The island endemics $H$. greefii and $H$. newtoni are genetically distinct lineages, suggesting a long evolutionary history on the islands. An additional undescribed species exists on São Tomé. 


\section{Acknowledgments}

This project was supported by grants from Fundação para a Ciência e Tecnologia (FCT) POCTI/41906/BSE/ 2001 and SFRH/BPD/5702/2001 (to D.J.H.). Fieldwork was also supported by an award from the Gulbenkian society (to D.J.H.). Thanks to the handling editor and two anonymous reviewers for their useful comments on an earlier draft of this manuscript.

\section{References}

Arnold, E.N., 2000. Using fossils and phylogenies to understand evolution of reptile communities on islands. In: Rheinwald, G. (Ed.), Isolated Vertebrate Communities in the Tropics. Bonn. Zoo. Monogr., vol. 46, pp. 309-323.

Austin, J.J., Arnold, E.N., Jones, C.G., 2004. Reconstructing an island radiation using ancient and recent DNA: the extinct and living day geckos (Phelsuma) of the Mascarene islands. Mol. Phylogenet. Evol. 31, 109-122.

Bandelt, H.-J., Macaulay, V., Richards, M.B., 2000. Median networks: speedy construction and greedy reduction, one simulation, and two case studies from human mtDNA. Mol. Phylogenet. Evol. 16, 8-28.

Brehm, A., Jesus, J., Spínola, H., Alves, C., Vicente, L., Harris, D.J., 2003. Phylogeography of the Madeiran endemic lizard Lacerta dugesii inferred from mtDNA sequences. Mol. Phylogenet. Evol. 26, 222-230.

Carranza, S., Arnold, E.N., Mateo, J.A., López-Jurado, L.F., 2000. Long-distance colonization and radiation in gekkonid lizards, Tarentola (Reptilia: Gekkonidae), revealed by mitochondrial DNA sequences. Proc. R. Soc. Lond. B 267, 637-649.

Carranza, S., Arnold, E.N., Mateo, J.A., López-Jurado, L.F., 2001. Parallel gigantism and complex colonization patterns in the Cape Verde scincid lizards Mabuya and Macroscincus (Reptilia: Scincidae) revealed by mitochondrial DNA sequences. Proc. R. Soc. Lond. B 268, 1595-1603.

Carranza, S., Arnold, E.N., Mateo, J.A., Geniez, P., 2002. Relationships and evolution of the North African geckos Geckonia and Tarentola (Reptilia: Gekkonidae), based on mitochondrial and nuclear DNA sequences. Mol. Phylogenet. Evol. 23, 244-256.

Felsenstein, J., 1981. Evolutionary trees from DNA sequences: a maximum likelihood approach. J. Mol. Evol. 17, 368-376.

Felsenstein, J., 1985. Confidence limits on phylogenies: an approach using the bootstrap. Evolution 39, 783-791

Friesen, V.L., Congdon, B.C., Walsh, H.E., Birt, T.P., 1997. Intron variation in marbled murrelets detected using analyses of singlestranded conformational polymorphisms. Mol. Ecol. 6, 1047-1058.

Harris, D.J., 2002. Reassessment of comparative genetic distance in reptiles from the mitochondrial cytochrome $b$ gene. Herp. J. 12, 85-86.

Harris, D.J., Arnold, E.N., Thomas, R.H., 1998. Relationships of the lacertid lizards (Reptilia: Lacertidae) estimated from mitochondrial DNA sequences and morphology. Proc. R. Soc. London B 265, 1939-1948.

Harris, D.J., Batista, V., Lymberakis, P., Carretero, M.A., 2004a. Complex estimates of evolutionary relationships in Tarentola mauritanica (Reptilia: Gekkonidae) derived from mitochondrial DNA sequences. Mol. Phylogenet. Evol. 30, 855-859.

Harris, D.J., Batista, V., Carretero, M.A., Ferrand, N., 2004b. Genetic variation in Tarentola mauritanica (Reptilia: Gekkonidae) across the Strait of Gibraltar derived from mitochondrial and nuclear DNA sequences. Amphibia-Reptilia 25, 451-459.

Huelsenbeck, J.P., Bollback, J.P., 2001. Emperical and hierarchical Bayesian estimation of ancestral states. Syst. Biol. 50, 351-366.

Hulsenbeck, J.P., Crandall, K.A., 1997. Phylogeny estimation and hypothesis testing using maximum likelihood. Ann. Rev. Ecol. Syst. $28,437-466$

Huelsenbeck, J.P., Ronquist, F., 2001. MR-BAYES: Bayesian inference of phylogeny. Bioinformatics 17, 754-755.

Jesus, J., Brehm, A., Harris, D.J., 2001. Relationships of Hemidactylus (Reptilia: Gekkonidae) from the Cape Verde islands: what mitochondrial DNA data indicate. J. Herpetol. 35, 672-675.

Jesus, J., Brehm, A., Harris, D.J., 2002a. Relationships of Tarentola (Reptilia: Gekkonidae) from the Cape Verde Islands estimated from DNA sequence data. Amphibia-Reptilia 22, 235-242.

Jesus, J., Freitas, A.I., Brehm, A., Harris, J., 2002b. An introduced population of Hemidactylus mabouia (Moreau de Jonnes, 1818) on Madeira island. Herpetozoa 15, 179-180.

Jesus, J., Brehm, A., Harris, D.J., 2003. The herpetofauna of Annobon island, Gulf of Guinea, West Africa. Br. Herp. Soc. Bull. 86, 20-22.

Kocher, T.D., Thomas, W.K., Meyer, A., Edwards, S.V., Pääbo, S., Villablanca, F.X., Wilson, A.C., 1989. Dynamics of mitochondrial evolution in animals: amplification and sequencing with conserved primers. Proc. Nat. Acad. Sci. USA 86, 6196-6200.

Lee, D.C., Halliday, A., Fitton, J., Poli, G., 1994. Isotopic variations with distances and time in the volcanic islands of the Cameroon line: evidence for a mantle plume origin. Earth Planet Sci. Lett. 123, $119-138$.

Myers, N., Mittermeier, R.A., Mittermeier, C.G., da Fonseca, G.A.B., Kent, J., 2000. Biodiversity hotspots for conservation priorities Nature 403, 853-858.

Posada, D., Crandall, K.A., 1998. Modeltest: testing the model of DNA substitution. Bioinformatics 14, 817-818.

Posada, D., Crandall, K.A., 2001. Selecting models of nucleotide substitution: an application to human immunodeficiency virus 1 (HIV-1). Mol. Biol. Evol. 18, 897-906.

Saint, K.M., Austin, C.C., Donnellan, S.C., Hutchinson, M.N., 1998. $\mathrm{C}$-mos, a nuclear marker useful for squamate phylogenetic analysis. Mol. Phylogenet. Evol. 10, 259-263.

Sambrook, J., Fritsch, E.F., Maniatis, T., 1989. Molecular Cloning: A Laboratory Manual, second ed. Cold Spring Harbour Press, New York.

Swofford, D.L., 2003. PAUP*: Phylogenetic Analysis Using Parsimony (and other methods) 4.0.b10. Sinauer Associates, Sunderland, Massachusetts, USA.

Thompson, J.D., Higgins, D.G., Gibson, T.J., 1994. Clustal W: improving the sensitivity of progressive multiple sequence alignment through sequence weighting, position specific gap penalties and weight matrix choice. Nucleic Acids Res. 22, 4673-4680.

Thorpe, R.S., McGregor, D.P., Cumming, A.M., Jordan, W.C., 1994. DNA evolution and colonization sequence of island lizards in relation to geological history: mtDNA RFLP, cytochrome $b$, cytochrome oxidase I, 12S rRNA sequence and nuclear RAPD analysis. Evolution 48, 230-240.

Vences, M., Wanke, S., Vietes, D.R., Branch, W.R., Glaw, F., Meyer, A., 2004. Natural colonization or introduction? Phylogeographic relationships and morphological differentiation of house geckos (Hemidactylus) from Madagascar. Biol. J. Linn. Soc. 83, 115130

Whiting, A.S., Bauer, A.M., Sites Jr., J.W., 2003. Phylogenetic relationships and limb loss in sub-Saharan African scincine lizards (Squamata: Scincidae). Mol. Phylogenet. Evol. 29, 582-598. 